\title{
Microbial Risk Assessment of a Bovine Slaughtering Unit in Bistriţa-Năsăud County
}

\author{
Oana REGET*, Alexandra TĂBĂRAN, Sorin Daniel DAN, Ionuţ CORDIŞ, Dana Liana PUSTA, \\ Marian MIHAIU \\ ${ }^{1}$ Faculty of Veterinary Medicine, University of Agricultural Sciences and Veterinary Medicine, Mănăștur \\ Street, no.3/5, Cluj-Napoca, Romania \\ *Corresponding author: oanalucia88@yahoo.co.uk
}

Bulletin UASVM Veterinary Medicine 73(1) / 2016,

Print ISSN 1843-5270; Electronic ISSN 1843-5378

DOI:10.15835/buasvmcn-vm: 11494

\begin{abstract}
Beef is favorable environment for microorganisms spoilage, for that reason, special attention should be paid to hygiene rules in obtaining carcass microbial load as low as the legislation requires.

The aim of our research was to perform an analysis of biological risks posed by total germ count, the total Enterobacteriaceae count and Salmonella spp. from a unit in Bistrița-Năsăud.

The research was conducted between January and December 2014 in the Department of Inspection and Control Animal Origin Food in the Faculty of Veterinary Medicine Cluj-Napoca.

The conclusions from the research were: total plate coun on the carcasses surface, studied, ranged between 2.43 and $2.53 \log _{10} \mathrm{cfu} / \mathrm{cm}^{2}$ values falling within the limits of REG. 2073/2005, as cataloged in the category satisfactory; for the total load Enterobacteriaceae on carcasses taken in the study, the values were between 1.25 and $1.41 \log _{10}$ $\mathrm{cfu} / \mathrm{cm}^{2}$, test results meet the requirements REG.2073/2005; regarding the identification of Salmonella spp, all samples were negative.
\end{abstract}

Keywords: bovine, microbial risks, slaughterhouse

\section{INTRODUCTION}

Although various foods can serve as a proper environment meat is an important sources of human infections with a variety of foodborne pathogens, i.e. Salmonella spp ., Campylobacter jejuni/coli, Yersinia enterocolitica, E. coli and, to some extent, Listeria monocytogenes. All these may be harboured in the gastrointestinal tract of food-producing animals. The most frequent chain of events leading to meat-borne illness involves food animals, which are healthy carriers of the pathogens that are subsequently transferred to humans through production, handling and consumption of meat and meat products. Occurrences of pathogens in fresh red meat vary relatively widely, although most often are between 1 and 10\%, depending on a range of factors including the organism, geographical factors, farming and/or slaughteringt practices.
During slaughtering the main source of contamination are animals slaughtered itself, but also the staff and working environment (Bell and Hathwaz, 1996). Contamination of equipment, materials and personnel hands can spread harmful bacteria on contaminated carcasses. Despite the fact that most microbial contaminants are bacteria comenesale, certain microorganisms such as Salmonella spp., E. coli 0157: H7 and Listeria monocytogenes is a threat to consumer health.

Contamination and/or cross-contamination of carcasses during slaughter operation was demonstrated and the results indicated the presence of bacteria that represent a risk to public health. The poor hand hygiene manipulator clothes and equipment slaughterhouse acts as intermediate sources contaminating meat (Gill, 1998; Gilmour et al., 2004; Abdalla et al., 2009). Also, Ali (2007) recorded high levels of 
contamination in the lower levels of the flank and the croup region, during skinning. Furthermore, Yalcin et al. (2001) showed that the load of coliform bacteria is mainly localized in the chest and shoulder, while the thigh was the least affected. This was explained by the positioning of the carcass during the slaughtering process, which is suspended and undergoes a constant change in the microbes from the rear region to the previous one.

Salmonella spp. has been widely identified in cattle and the infected animals may carry these bacteria without any clinical symptoms (Narvaez-Bravo et al. 2013). the routes of pathogen transmission also include contaminated slaughter-house equipment, dust, operator hands, or technological water. These ways of bacteria transfer emphasise the importance of controls in the food chain to prevent transmission of Salmonella and other foodborne pathogens (Rhoades et al., 1998; Sofos et al.,1999).

\section{MATERIALS AND METHODS}

The material under investigation was represented by 12 samplegatheringsessionsduring January-December 2014 from a slaughterhouse in Bistrița-Năsăud county. Samples were collected from the carcass immediately after slaughtering quarters. Sampling was done randomly, from carcases obtained both at the beginning and at the end of cut. Sampling was conducted from the surface, respecting the norms recommended by the National Sanitary Veterinary and Food Safety Agency as follows: at each sampling session shall be sampled at random from five carcasses. When sampling for analyzes of Enterobacteriaceae and aerobic colony count was carried out in four sites of each carcase. Four tissue samples representing a total area of $20 \mathrm{~cm}^{2}$ were obtained. The samples for Salmonella testing were gathered using the abrasive sponge method, the most likely to be contaminated areas were selected and the total sampling area was about $400 \mathrm{~cm}^{2}$.

Samples were placed in Petri dishes with a diameter of $15 \mathrm{~cm}$ and immediately transported to the laboratory discipline of Animal Hygiene and Public Health in the Faculty of Veterinary Medicine Cluj-Napoca.

The isolation of the pathogens present on the carcasses surface was made on account of the standardize methods in conformity with the Reg. (EC) 1441/2007: the Enterobacteriaceae identification respecting SR ISO 21528/2007, the aerobic plate count following SR ISO 4833/2003 the identification of Salmonella spp. respecting SR EN ISO 6579/2003 AC/2006. The results were

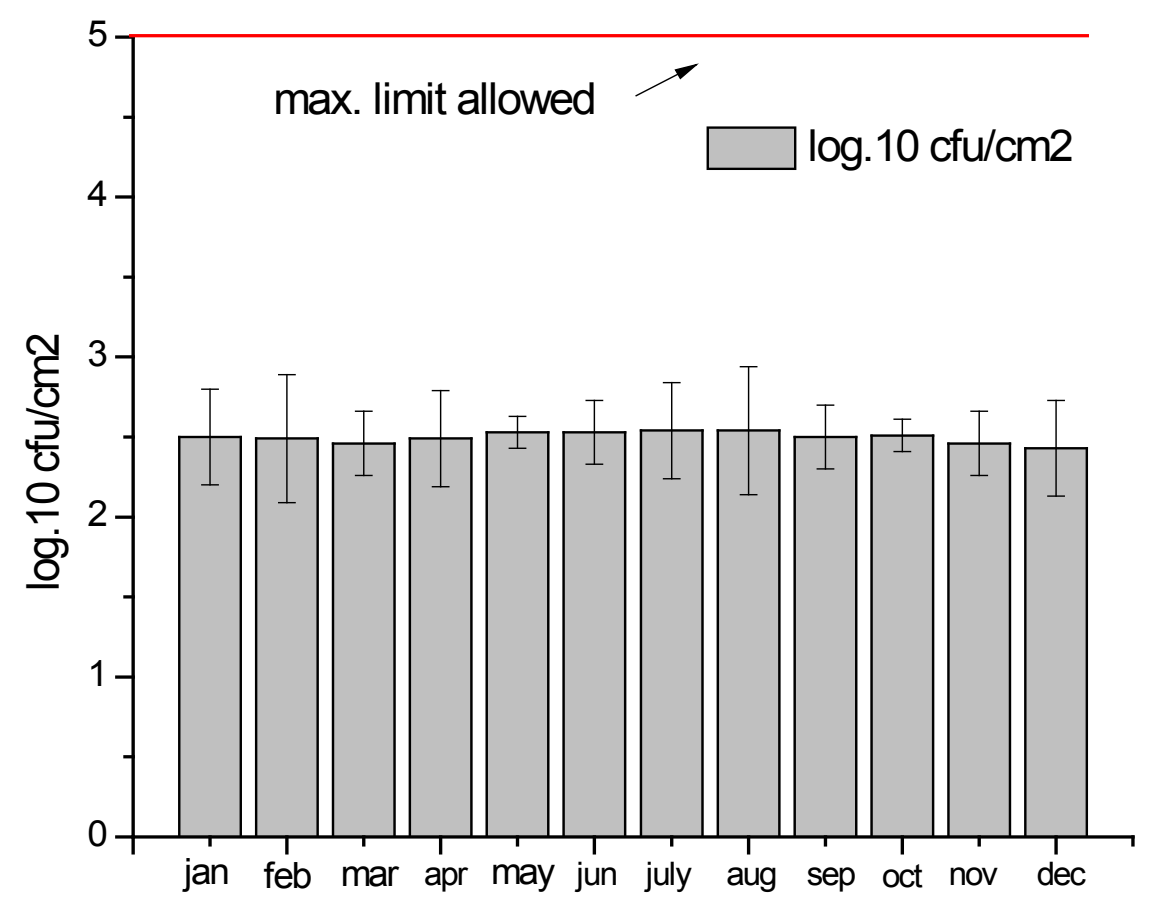

Fig. 1. Evolution of aerobic plate count during the period under study 
analyzed statistical and mathematical using the Origin 8.5 program.

\section{RESULTS AND DISCUSSION}

The initial microbial configuration of the carcass and microbial load is determined by the health of the animal before slaughter, housing conditions and by the transportation conditions. TGC is also dependent on strict compliance with the hygienic process flow.

As seen from Fig. 1., for all months studied the number of colony forming units fall within the limits prescribed by law, namely between 2.43 and $2.53 \log _{10} \mathrm{cfu} / \mathrm{cm}^{2}$.

From the analyze of the data obtained was found that the in studied unit, the minimum value for the TGC was $2.43 \log _{10} \mathrm{cfu} / \mathrm{cm}^{2}$ in December of 2014 and the peak value was recorded in July and August of the same year, $2.54 \log _{10} \mathrm{cfu} / \mathrm{cm}^{2}$ (Figure 1.). We can also state that in any of the months, the maximum permissible value of $5 \log _{10} \mathrm{cfu} / \mathrm{cm}^{2}$, was not exceeded.

Comparing the results recorded in the summer months, with the ones in winter we can see that the average value of TGC during summer months (represented by June, July, August) is higher, compared to the average value during the winter (represented December, January, February). These values are correlated with the increasing temperature depending on the season.
It can be seen in Figure 1. that most of the values obtained are below the lower limit described in REG. $2073 / 2005$, namely $83 \%$ of the cases considered. In $7 \%$ of the cases, the values reach the minimul value. None of the values recorded exceeded the upper limit.

The effect of seasonal bacterial contamination was studied by Dennie and collaborators (2001) , Barkocy-Gallagher et al. (2003) and McEvoi et al. (2003) which showed that maximum TGC values are recorded during summer moths.

Analyzing the results obtained throughout the study period we observed that the minimum value was recorded in January and was $1.25 \log _{10} \mathrm{cfu} / \mathrm{cm}^{2}$ . The maximum value recorded was lower, than maximum amount stipulated in the regulations. Given the time of year this result can be attributed to the high temperature of the month.

Regarding the identification of Salmonella spp., this objective represents a very important part and of great interest because of the high incidence of food poisoning. After conducting the identification protocol, it was found that none of the samples tested positive for Salmonella spp. This is according to the regulations, that stipulated that salmonella spp. must be absent. Our study may correlate with the one made by Movassagh et al. (2010), in which 75 carcasses of cattle were studied, and all samples tested were negative for Salmonella spp.

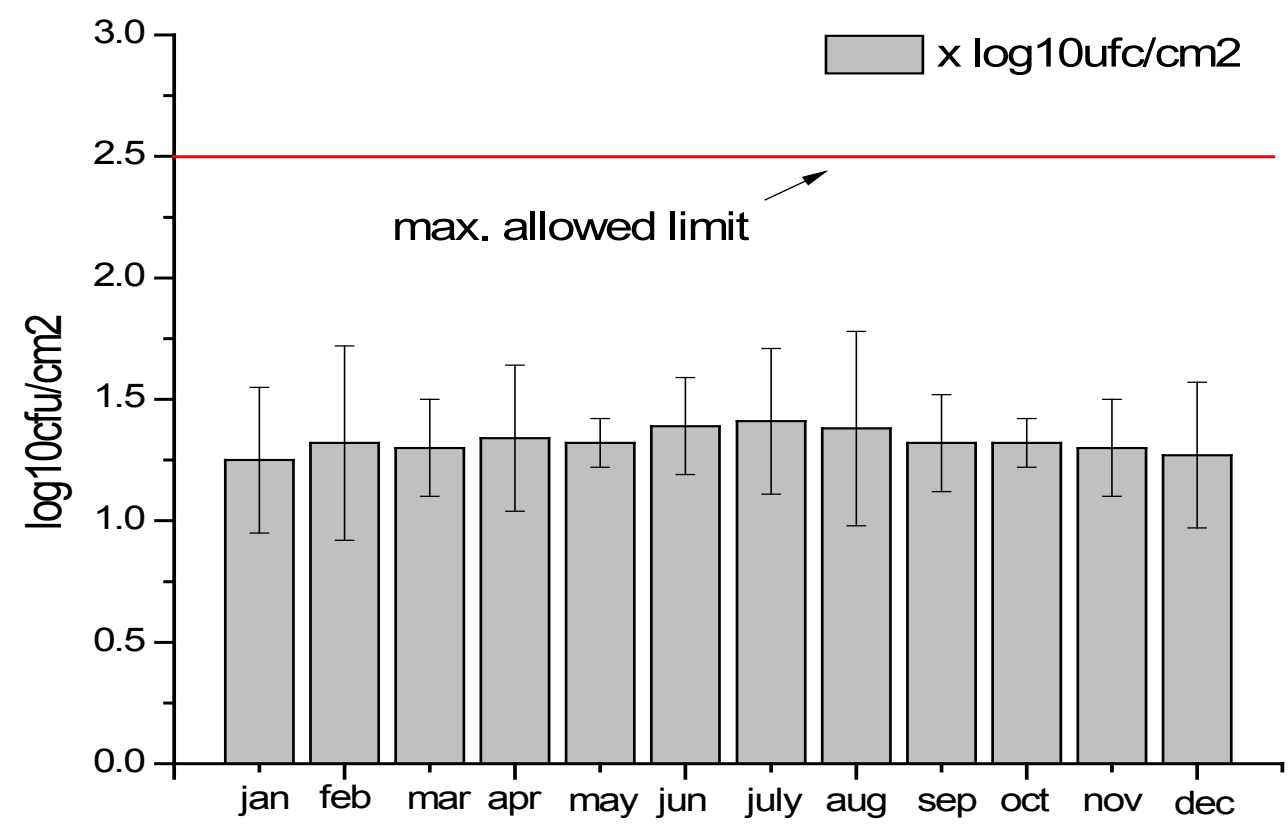

Fig. 2. Evolution of Enterobacteriaceae count during the period under study 


\section{CONCLUSION}

From the the total samples analyzed regarding the aerobic plate count none exceeded the maximum admitted value. Also the values obtained for the total enterobacteriaceae count were according to the regulations. The highest values both for the aerobic plate cont and Enterobacteriaceae were found during summer months due to higher temperature. We mention the fact that Salmonella spp. pathogens were not identified.

\section{REFERENCES}

1. Abdalla MA, Suliman SE, Ahmed DE, Bakhiet AO (2009). Estimation of bacterial contamination of indigenous bovine carcasses in Khartoum (Sudan). African Journal of Microbiologiy Research 3(10):882-886.

2. Ali AA (2007). Prevalence of bacterial contamination of public Health concern on bovine carcasses at Kartoum state-Sudan. M.Sc.Thesis, Sudan University of Science and Technology, 78-85.

3. Barkocy-Gallagher GA, Arthur TM, Rivera-Betancourt M., Nou X, Shackelford SD, Wheeler TL, Koohmaraie M (2003). Seasonal prevalence of Shiga toxin-producing Escherichia coli, including 0157:H7 and non-0157:H7 serotypes, and Salmonella in commercial beef processing plants. J Food Prot 66:1978-1986.

4. Bell RG, Hathway SC (1996). The hygienic efficiency of conventional and inverted lamb dressing systems. Journal Of Applied Microbiology 81:225-234.

5. Biss ME, Hathaway SC (1995). Microbiological and visible contamination of bovine carcasses acording to preslaughter presentation status:Implications for HACCP. Journal of Food Protection 63:1080-1086.
6. Gill CO (2000). HACCP in primary processing red meat WoodHead Publishing, Cambridge, 81-122.

7. Gilmour A, Murry KA, Madden RH (2004). Determination of the principal points of product contamination during beef carcass dressing process in Northern Ireland. Journal of Food Protection 67:1494-1497.

8. McEvoy JM, Doherty AM, Sheridan JJ, Thomson-Carter FM, Garvey P, McGuire L, Blair IS, McDowell DA (2003). The prevalence and spread of Escherichia coli 0157:H7 at a commercial beef abattoir. J Appl Microbiol 95:256-266.

9. Narvaez-Bravo C, Rodas-Gonzalez A, Fuenmayor Y, Flores-Rondon C, Carruyo G, Moreno M, Perozo-Mena A, Hoet AE (2013). Salmonella on feces, hides and carcasses in beef slaughter facilities in Venezuela. Intern J Food Microbiol, 166, 226-230.

10. Rhoades JR, Duffy G, Koutsoumanis K (2009). Prevalence and concentration of verocytotoxigenic Escherichia coli, Salmonella enterica and Listeria monocytogenes in the beef production chain: a review. Food Microbiol 26:357376.

11. Sofos JN, Kochevar SL, Reagan JO, Smith GC (1999). Incidence of Salmonella on beef carcasses relating to the US meat and poultry inspection regulations. J Food Prot 62:467-473.

12. *** Regulamentul (CE) nr.1441/2007 al Comisiei din 5 decembrie 2007 de modificare a Regulamentului (CE) nr. 2073/2005 privind criteriile microbiologice pentru produsele alimentare.

13. *** SR EN ISO 6579/2003, SR EN ISO 6579 AC/2009. Metoda orizontală pentru detectarea bacteriilor din genul Salmonella.

14. ${ }^{* * *}$ SR EN ISO 4833/2003. Metoda orizontală pentru enumerarea microorganismelor. Tehnica de enumerare a coloniilor la $30{ }^{\circ} \mathrm{C}$.

15. ***SR ISO 21528-2/2007. Metoda orizontală pentru enumerarea germenilor din familia Enterobacteriaceae. 